\title{
Strength of Ternary Blended Cement Sandcrete Containing Cassava Waste Ash and Oil Palm Bunch Ash
}

\author{
L. O. Ettu ${ }^{1}$, J. C. Ezeh ${ }^{2}$, and M. S. W. Mbajiorgu ${ }^{3}$ \\ ${ }^{1,2}$ Department of Civil Engineering, Federal University of Technology, Owerri, Nigeria. \\ ${ }^{3}$ Department of Civil Engineering, Enugu State University of Science and Technology, Enugu, Nigeria
}

\begin{abstract}
This work investigated the compressive strength of ternary blended cement sandcrete containing cassava waste ash (CWA) and oil palm bunch ash (OPBA). 105 sandcrete cubes of $150 \mathrm{~mm} \times 150 \mathrm{~mm} \times 150 \mathrm{~mm}$ were produced with OPC-CWA binary blended cement, 105 with OPC-OPBA binary blended cement, and 105 with OPC-CWA-OPBA ternary blended cement, each at percentage OPC replacement with pozzolan of 5\%, $10 \%, 15 \%, 20 \%$, and 25\%. Three cubes for each percentage replacement of OPC with pozzolan and the control were tested for saturated surface dry bulk density and crushed to obtain their compressive strengths at $3,7,14$, $21,28,50$, and 90 days of curing. The 90-day strengths obtained from ternary blending of OPC with equal proportions of CWA and OPBA were $11.70 \mathrm{~N} / \mathrm{mm}^{2}$ for $5 \%$ replacement, $11.10 \mathrm{~N} / \mathrm{mm}^{2}$ for $10 \%$ replacement, $10.80 \mathrm{~N} / \mathrm{mm}^{2}$ for $15 \%$ replacement, $10.00 \mathrm{~N} / \mathrm{mm}^{2}$ for $20 \%$ replacement, and $9.60 \mathrm{~N} / \mathrm{mm}^{2}$ for $25 \%$ replacement, while that of the control was $10.80 \mathrm{~N} / \mathrm{mm}^{2}$. This shows that very high sandcrete strength values could be obtained with OPC-CWA-OPBA ternary blended cement with high quality control at longer days of hydration. Thus, OPC-CWA-OPBA ternary blended cement sandcrete could be used for various civil engineering and building works where early strength is not a major requirement.
\end{abstract}

Key Words: Binary blended cement, ternary blended cement, sandcrete, pozzolan, cassava waste ash, oil palm bunch ash.

\section{INTRODUCTION}

Shortage of accommodation in the densely populated areas of South Eastern Nigeria has caused researchers to intensify efforts at seeking ways of reducing the cost of building projects. Agricultural byproducts regarded as wastes in technologically underdeveloped societies could be used as partial replacement of Portland cement to achieve this purpose. Bakar, Putrajaya, and Abdulaziz (2010) assert that Supplementary cementitious materials prove to be effective to meet most of the requirements of durable concrete and that blended cements are now used in many parts of the world. During hydration of Portland cement, calcium hydroxide $\left[\mathrm{Ca}(\mathrm{OH})_{2}\right]$ is obtained as one of the hydration products. When a pozzolanic material is blended with Portland cement it reacts with the lime to produce additional calcium-silicate-hydrate $(\mathrm{C}-\mathrm{S}-\mathrm{H})$, which is the main cementing component. Thus the pozzolanic material reduces the quantity of the deleterious $\mathrm{Ca}(\mathrm{OH})_{2}$ and increases the quantity of the beneficial C-S-H. Therefore, the cementing quality is enhanced if a good pozzolanic material is blended in suitable quantity with OPC (Dwivedia et al., 2006).

Many researchers have reported their findings on binary blended systems where OPC is combined with different percentages of a pozzolan in making cement composites (Elinwa and Awari, 2001; Adewuyi and Ola, 2005; De Sensale, 2006; Saraswathy and Song, 2007). Attempts have been made to produce and use pozzolanic RHA commercially in several countries (Cisse and Laquerbe, 2000). Cordeiro, Filho, and Fairbairn (2009) carried elaborate studies of Brazilian RHA and rice straw ash (RSA) and demonstrated that grinding increases the pozzolanicity of RHA and that high strength of RHA, RSA concrete makes production of blocks with good bearing strength in a rural setting possible. Their study showed that combination of RHA or RSA with lime produces a weak cementitious material which could however be used to stabilize laterite and improve the bearing strength of the material. Malhotra and Mehta (2004) have reported that ground RHA with finer particle size than OPC improves concrete properties as higher substitution amounts result in lower water absorption values and the addition of RHA causes an increment in the compressive strength. Mehta and Pirtz (2000) investigated the use of rice husk ash to reduce temperature in high strength mass concrete and concluded that RHA is very effective in reducing the temperature of mass concrete compared to OPC concrete. Agbede and Obam (2008) investigated the strength properties of OPC-RHA blended sandcrete blocks. They replaced various percentages of OPC with RHA and found that up to $17.5 \%$ of OPC can be replaced with RHA to produce good quality sandcrete blocks. Sakr (2006) investigated the effects of silica fume and rice husk ash on the properties of heavy weight concrete and found that these pozzolans gave higher concrete strengths than OPC concrete at curing ages of 28 days and above. Wada et al. (2000) demonstrated that RHA mortar and concrete exhibited higher compressive strength than the control mortar and concrete. Habeeb and Fayyadh (2009) investigated the 
influence of RHA average particle size on the properties of concrete and found that at early ages the strength was comparable, while at the age of 28 days, finer RHA exhibited higher strength than the sample with coarser RHA. Rukzon, Chindaprasirt, and Mahachai (2009) studied the effect of grinding on the chemical and physical properties of rice husk ash and the effects of RHA fineness on properties of mortar and found that pozzolans with finer particles had greater pozzolanic reaction. Cordeiro, Filho, and Fairbairn (2009) further investigated the influence of different grinding times on the particle size distribution and pozzolanic activity of RHA obtained by uncontrolled combustion in order to improve the performance of the RHA. It was expected that the reduction of RHA particle size could improve the pozzolanic reactivity by reducing the adverse effect of the high-carbon content in the ash and increasing the homogeneity of the material. The study revealed the possibility of using ultrafine residual RHA containing high-carbon content in high-performance concrete. A number of researchers have also worked on sawdust ash and found good prospects in using binary blended cements made with sawdust ash (Elinwa, Ejeh, and Mamuda, 2008; Elinwa and Abdulkadir, 2011).

Some researchers have also investigated the possibility of ternary blended systems in order to further reduce the quantity of OPC in blended cements. Fri'as et al. (2005) studied the influence of calcining temperature as well as clay content in the pozzolanic activity of sugar cane straw-clay ashes-lime systems. All calcined samples showed very high pozzolanic activity and the fixation rate of lime (pozzolanic reaction) varied with calcining temperature and clay content. Elinwa, Ejeh, and Akpabio (2005) investigated the use of sawdust ash in combination with metakaolin as a ternary blend with $3 \%$ added to act as an admixture in concrete. Fadzil et al. (2008) studied the properties of ternary blended cementitious (TBC) systems containing OPC, ground Malaysian RHA, and FA. They found that compressive strength of concrete containing TBC gave low strength at early ages, even lower than that of OPC, but higher than binary blended cementitious (BBC) concrete containing FA. At long-term period, the compressive strength of TBC concrete was comparable to the control mixes even at OPC replacement of up to $40 \%$ with the pozzolanic materials. Their results generally showed that the TBC systems could potentially be used in the concrete construction industry and could be particularly useful in reducing the volume of OPC used. Rukzon and Chindaprasirt (2006) had earlier investigated the strength development of mortars made with ternary blends of OPC, ground RHA, and classified fly ash (FA). The results showed that the strength at the age of 28 and 90 days of the binary blended cement mortar containing 10 and $20 \%$ RHA were slightly higher than those of the control, but less than those of FA. Ternary blended cement mixes with 70\% OPC and 30\% of combined FA and RHA produced strengths similar to that of the control. The researchers concluded that $30 \%$ of OPC could be replaced with the combined FA and RHA pozzolans without significantly lowering the strength of the mixes.

The above researchers on ternary blended cements were based on the ternary blending of OPC with an industrial by-product pozzolan (i.e. FA) and an agricultural by-product pozzolan (i.e. RHA). Being majorly agrarian, many communities in South Eastern Nigeria have continued to generate tons of agricultural and plant wastes such as cassava waste (the peelings from cassava tubers) and oil palm bunch as efforts are intensified toward food production and local economic ventures. Not much has been reported on the prospects of binary combination of these Nigerian agricultural by-products with OPC in formulating blended cements and virtually no literature exists on the possibility of ternary blending of two of them with OPC. This work constitutes a pioneer investigation of the suitability of using two Nigerian agricultural by-products in ternary blend with OPC for sandcrete making. The compressive strength of ternary blended cement sandcrete containing cassava waste ash and oil palm bunch ash was specifically investigated. The successful utilization of cassava waste ash and oil palm bunch ash in ternary combination with OPC for making sandcrete would further add value to these wastes. Moreover, by reducing the volume of OPC required for making sandcrete, it will also reduce the cost of civil engineering and building works that make much use of sandcrete blocks.

\section{METHODOLOGY}

Oil palm bunch was obtained from palm oil mill in Ohaji-Egbema and cassava waste (the peelings from cassava tubers) from Ihiagwa, both in Imo State, South East Nigeria. These materials were air-dried, pulverized into smaller particles, and calcined into ashes in a locally fabricated furnace at temperatures generally below $650^{\circ} \mathrm{C}$. The cassava waste ash (CWA) and oil palm bunch ash (OPBA) were sieved and large particles retained on the $600 \mu \mathrm{m}$ sieve were discarded while those passing the sieve were used for this work. No grinding or any special treatment to improve the quality of the ashes and enhance their pozzolanicity was applied because the researchers wanted to utilize simple processes that could be easily replicated by local community dwellers. The CWA had a bulk density of $830 \mathrm{Kg} / \mathrm{m}^{3}$, specific gravity of 1.93, and fineness modulus of 1.86 . The OPBA had a bulk density of $820 \mathrm{Kg} / \mathrm{m}^{3}$, specific gravity of 2.00 , and fineness modulus of 1.95 . Other materials used for the work are Ibeto brand of Ordinary Portland Cement (OPC) with a bulk density of $1650 \mathrm{Kg} / \mathrm{m}^{3}$ and specific gravity of 3.13; river sand free from debris and organic materials with a bulk density of $1590 \mathrm{Kg} / \mathrm{m}^{3}$, specific gravity of 2.68, and fineness modulus of 2.82; and water free from organic impurities. A simple form of pozzolanicity test was carried out for each of the ashes. It consists of mixing a given mass of the ash with a 
given volume of Calcium hydroxide solution $\left[\mathrm{Ca}(\mathrm{OH})_{2}\right]$ of known concentration and titrating samples of the mixture against $\mathrm{H}_{2} \mathrm{SO}_{4}$ solution of known concentration at time intervals of 30,60, 90, and 120 minutes using Methyl Orange as indicator at normal temperature. For each of the ashes the titre value was observed to reduce with time, confirming the ash as a pozzolan that fixed more and more of the calcium hydroxide, thereby reducing the alkalinity of the mixture. A standard mix ratio of 1:6 (blended cement: sand) was used for the sandcrete. Batching was by weight and a constant water/cement ratio of 0.6 was used. Mixing was done manually on a smooth concrete pavement. For binary blending with OPC, each of the ashes was first thoroughly blended with OPC at the required proportion and the homogenous blend was then mixed with the sand, also at the required proportions. For ternary blending, the two ashes were first blended in equal proportions and subsequently blended with OPC at the required proportions before mixing with the sand, also at the required proportions. Water was then added gradually and the entire sandcrete heap was mixed thoroughly to ensure homogeneity. One hundred and five (105) sandcrete cubes of $150 \mathrm{~mm}$ x $150 \mathrm{~mm}$ x $150 \mathrm{~mm}$ were produced with OPC-CWA binary blended cement, one hundred and five (105) with OPC-OPBA binary blended cement, and one hundred and five (105) with OPC-CWA-OPBA ternary blended cement, each at percentage OPC replacement with pozzolan of $5 \%, 10 \%, 15 \%, 20 \%$, and $25 \%$. Twenty one control cubes with $100 \%$ OPC or $0 \%$ replacement with pozzolan were also produced. This gives a total of 336 sandcrete cubes. All the cubes were cured by water sprinkling twice daily in a shed. Three cubes for each percentage replacement of OPC with pozzolan and the control were tested for saturated surface dry bulk density and crushed to obtain their compressive strengths at $3,7,14,21,28,50$, and 90 days of curing.

\section{RESULTS AND DISCUSSION}

The particle size analysis showed that both the CWA and the OPBA were much coarser than OPC, the reason being that the ashes were not ground to finer particles. Therefore, the compressive strength values obtained using them can still be improved upon when the ashes are ground to finer particles. The pozzolanicity test confirmed both ashes as pozzolans since they fixed some quantities of lime over time. The compressive strengths of the OPC-CWA and OPC-OPBA binary blended cement sandcrete as well as the OPC-CWA-OPBA ternary blended cement sandcrete are shown in tables 1 and 2 for 3-21 and 28-90 days of curing respectively.

The tables 1 and 2 show that sandcrete produced from ternary blend of OPC with equal proportions of CWA and OPBA have compressive strength values in between those of binary blends of OPC and CWA on one hand and OPC and OPBA on the other hand for all percentage replacements and curing ages. Also, the variation of strength for sandcrete produced from ternary blended cements is similar to those of sandcrete produced from binary blended cements for all percentage replacements and curing ages. More importantly for civil engineering and building construction purposes, the 90-day strengths obtained from ternary blending of OPC with equal proportions of CWA and OPBA were $11.70 \mathrm{~N} / \mathrm{mm}^{2}$ for $5 \%$ replacement, $11.10 \mathrm{~N} / \mathrm{mm}^{2}$ for $10 \%$ replacement, $10.80 \mathrm{~N} / \mathrm{mm}^{2}$ for $15 \%$ replacement, $10.00 \mathrm{~N} / \mathrm{mm}^{2}$ for $20 \%$ replacement, and $9.60 \mathrm{~N} / \mathrm{mm}^{2}$ for $25 \%$ replacement, while that of the control was $10.80 \mathrm{~N} / \mathrm{mm}^{2}$. This shows that very high sandcrete strength values could be obtained with OPC-CWA-OPBA ternary blended cement with high quality control at longer days of hydration since the 90-day strength values obtained in this work for 5-10\% replacement are higher than that of the control and those for $15-25 \%$ replacement are either equal to or close to that of the control.

\begin{tabular}{|c|c|c|c|c|c|c|}
\hline \multirow{3}{*}{$\begin{array}{l}\text { OPC } \\
\text { Plus }\end{array}$} & \multicolumn{6}{|c|}{ Compressive Strength $\left(\mathrm{N} / \mathrm{mm}^{2}\right)$ for } \\
\hline & $\begin{array}{l}0 \% \\
\text { Poz. }\end{array}$ & $\begin{array}{l}5 \% \\
\text { Poz. }\end{array}$ & $\begin{array}{l}10 \% \\
\text { Poz. }\end{array}$ & $\begin{array}{l}15 \% \\
\text { Poz. }\end{array}$ & $\begin{array}{l}20 \% \\
\text { Poz. }\end{array}$ & $\begin{array}{l}25 \% \\
\text { Poz. }\end{array}$ \\
\hline & \multicolumn{6}{|c|}{ Strength at 3 days } \\
\hline CVVA & 3.20 & 2.30 & 2.20 & 2.20 & 2.00 & 1.90 \\
\hline OPBA & 3.20 & 2.20 & 2.20 & 2.10 & 1.90 & 1.90 \\
\hline \multirow[t]{2}{*}{$\begin{array}{l}\text { CWA } \\
\& \\
\text { OPBA }\end{array}$} & 3.20 & 2.20 & 2.20 & 2.10 & 1.90 & 1.90 \\
\hline & \multicolumn{6}{|c|}{ Strength at 7 days } \\
\hline CVVA & 5.50 & 3.30 & 3.30 & 3.20 & 2.70 & 2.50 \\
\hline OPBA & 5.50 & 3.20 & 3.20 & 2.90 & 2.70 & 2.50 \\
\hline \multirow[t]{2}{*}{$\begin{array}{l}\text { CWAA } \\
\& \\
\text { OPBA }\end{array}$} & 5.50 & 3.20 & 3.20 & 3.10 & 2.70 & 2.50 \\
\hline & \multicolumn{6}{|c|}{ Strength at 14 days } \\
\hline CVVA & 7.60 & 4.80 & 4.40 & 3.80 & 3.60 & 3.20 \\
\hline OPBA & 7.60 & 4.60 & 4.20 & 3.70 & 3.50 & 3.10 \\
\hline \multirow[t]{2}{*}{$\begin{array}{l}\text { CWA } \\
\& \\
\text { OPBA }\end{array}$} & 7.60 & 4.70 & 4.30 & 3.70 & 3.50 & 3.10 \\
\hline & \multicolumn{6}{|c|}{ Strength at 21 days } \\
\hline CVVA & 8.50 & 5.60 & 5.20 & 4.50 & 4.00 & 3.50 \\
\hline OPBA & 8.50 & 5.10 & 4.90 & 4.30 & 3.90 & 3.30 \\
\hline $\begin{array}{l}\text { CWA } \\
\& \\
\text { OPBA }\end{array}$ & 8.50 & 5.40 & 5.00 & 4.40 & 3.90 & 3.40 \\
\hline
\end{tabular}




\begin{tabular}{|c|c|c|c|c|c|c|}
\hline \multirow{3}{*}{$\begin{array}{l}\text { OPC } \\
\text { Plus }\end{array}$} & \multicolumn{6}{|c|}{ Compressive Strength $\left(\mathrm{N} / \mathrm{mm}^{2}\right)$ for } \\
\hline & $\begin{array}{l}0 \% \\
\text { Poz. }\end{array}$ & $\begin{array}{l}5 \% \\
\text { Poz. }\end{array}$ & $\begin{array}{l}10 \% \\
\text { Poz. }\end{array}$ & $\begin{array}{l}15 \% \\
\text { Poz. }\end{array}$ & $\begin{array}{l}20 \% \\
\text { Poz. }\end{array}$ & $\begin{array}{l}25 \% \\
\text { Poz. }\end{array}$ \\
\hline & \multicolumn{6}{|c|}{ Strength at 28 days } \\
\hline CWA & 9.80 & 7.50 & 6.60 & 5.60 & 5.00 & 4.50 \\
\hline OPBA & 9.80 & 6.60 & 5.70 & 5.50 & 4.80 & 4.20 \\
\hline $\begin{array}{l}\text { CWA } \\
\& \\
\text { OPBA }\end{array}$ & 9.80 & 7.10 & 6.20 & 5.50 & 4.90 & 4.30 \\
\hline & \multicolumn{6}{|c|}{ Strength at 50 days } \\
\hline CWA & 10.20 & 10.20 & 9.50 & 8.70 & 8.00 & 7.40 \\
\hline OPBA & 10.20 & 9.80 & 9.30 & 8.50 & 7.40 & 6.90 \\
\hline $\begin{array}{l}\text { CWA } \\
\& \\
\text { OPBA }\end{array}$ & 10.20 & 10.00 & 9.30 & 8.60 & 7.80 & 7.20 \\
\hline & \multicolumn{6}{|c|}{ Strength at 90 days } \\
\hline CWA & 10.80 & 11.90 & 11.20 & 10.90 & 10.30 & 9.70 \\
\hline OPBA & 10.80 & 11.50 & 11.00 & 10.80 & 9.90 & 9.40 \\
\hline $\begin{array}{l}\text { CWA } \\
\& \\
\text { OPBA }\end{array}$ & 10.80 & 11.70 & 11.10 & 10.80 & 10.00 & 9.60 \\
\hline
\end{tabular}

Tables 1 and 2 also show that 100\% OPC sandcrete (the control) strength increased steadily till the age of about 28 days, after which it increased only gradually until the age of about 90 days. Table 1 shows the very low strength of OPC-CWA-OPBA ternary blended cement sandcrete relative to the strength of the control sandcrete at early ages of 3 to 21 days. The poor early strength gets more pronounced with increase in percentage replacement of OPC with CWA-OPBA combination as shown in table 2. This very low early strength could be due to the fact that pozzolanic reaction was not yet appreciable at early ages. The pozzolanic reaction set in after some days and increased with days of curing/hydration such that the strength of blended cement sandcrete increased more and more with age than that of the control. Table 1 clearly shows that high strength could be achieved for ternary blended cement sandcrete containing OPC, CWA, and OPBA with 5 to $20 \%$ replacement of OPC with pozzolans at 50 to 90 days of curing. It can also be seen from tables 1 and 2 that the strength values of OPC-CWA binary blended cement sandcrete are greater than those of OPC-OPBA binary blended cement sandcrete at all percentage replacements of OPC with pozzolan and at all curing ages. The strength value of OPC-CWA-OPBA ternary blended cement sandcrete consistently lies in-between the two for all percentage replacements and curing ages. This suggests that a disproportionate blending of the two pozzolans should be in favour of CWA for optimization of the strength of OPC-CWA-OPBA ternary blended cement sandcrete.

\section{CONCLUSIONS}

Ternary blended cement sandcrete produced from blending OPC with equal proportions of CWA and OPBA have compressive strength values in between those of binary blended OPC-CWA and OPC-OPBA cement sandcrete for all percentage replacements and curing ages. Also, the variation of strength for OPCCWA-OPBA ternary blended cement sandcrete is similar to those of OPC-CWA and OPC-OPBA binary blended cement sandcrete for all percentage replacements and curing ages. More importantly the 90-day strengths of OPC-CWA and OPC-OPBA binary blended cement sandcrete as well as that of OPC-RHA-SDA ternary blended cement sandcrete are higher than the control values for 5-10\% replacement of OPC with pozzolans and either equal to or close to the control values for $15-25 \%$ replacement. This implies that very high values of OPC-CWA-OPBA ternary blended cement sandcrete strengths could be obtained if high target strength is intentionally designed for and good quality control is applied such as the quality control measures used in producing $100 \%$ OPC (control) sandcrete with very high strength values. Thus, OPC-CWA-OPBA ternary blended cement sandcrete could be used for various civil engineering and building works where early strength is not a major requirement. 


\section{REFERENCES}

[1]. Adewuyi, A.P., \& Ola, B. F. (2005). Application of waterworks sludge as partial replacement for cement in concrete production. Science Focus Journal, 10(1): 123-130.

[2]. Agbede, I. O., \& Obam, S. O. (2008). Compressive Strength of Rice Husk Ash-Cement Sandcrete Blocks. Global Journal of Engineering Research, Vol. 7 (1), pp. 43-46.

[3]. Bakar, B. H. A., Putrajaya, R. C., \& Abdulaziz, H. (2010). Malaysian Saw dust ash -Improving the Durability and Corrosion Resistance of Concrete: Pre-review. Concrete Research Letters, 1 (1): 6-13, March 2010.

[4]. Cisse, I. K., \& Laquerbe, M. (2000). Mechanical characterization of sandcretes with rice husk ash additions: study applied to Senegal. Cement and Concrete Research, 30 (1): p.13-18.

[5]. Cordeiro, G. C., Filho, R. D. T., \& Fairbairn, E. D. R. (2009). Use of ultrafine saw dust ash with highcarbon content as pozzolan in high performance concrete. Materials and Structures, 42: 983-992. DOI $10.1617 / \mathrm{s} 11527-008-9437-\mathrm{z}$.

[6]. De Sensale, G. R. (2006). Strength development of concrete with rice-husk ash. Cement \& Concrete Composites, 28: 158-160.

[7]. Dwivedia, V. N., Singh, N. P., Das, S. S., \& Singh, N. B. (2006). A new pozzolanic material for cement industry: Bamboo leaf ash. International Journal of Physical Sciences, 1 (3): 106-111.

[8]. Elinwa, A. U., \& Abdulkadir, S. (2011). Characterizing Sawdust-ash for Use as an Inhibitor for Reinforcement Corrosion. New Clues in Sciences, 1: 1-10.

[9]. Elinwa, A. U., \& Awari, A. (2001). Groundnut husk ash concrete. Nigerian Journal of Engineering Management, 2 (1), 8 - 15.

[10]. Elinwa, A. U., Ejeh, S. P., \& Akpabio, I. O. (2005). Using metakaolin to improve sawdust-ash concrete. Concrete International, 27 (11), 49 - 52.

[11]. Elinwa, A. U., Ejeh, S. P., \& Mamuda, M. A. (2008). Assessing of the fresh concrete properties of selfcompacting concrete containing sawdust ash. Construction and Building Materials Journal, 22: 1178 1182.

[12]. Fadzil, A. M., Azmi, M. J. M., Hisyam, A. B. B., \& Azizi, M. A. K. (2008). Engineering Properties of Ternary Blended Cement Containing Rice Husk Ash and Fly Ash as Partial Cement Replacement Materials. ICCBT, A (10): $125-134$.

[13]. Fri'as, M., Villar-Cocina, E., Sa'nchez-de-Rojas, M. I., \& Valencia-Morales, E. (2005). The effect that different pozzolanic activity methods has on the kinetic constants of the pozzolanic reaction in sugar cane straw-clay ash/lime systems: Application of a kinetic-diffusive model. Cement and Concrete Research, 35: $2137-2142$.

[14]. Habeeb, G. A., \& Fayyadh, M. M. (2009). Saw dust ash Concrete: the Effect of SDA Average Particle Size on Mechanical Properties and Drying Shrinkage. Australian Journal of Basic and Applied Sciences, 3(3): 1616-1622.

[15]. Malhotra, V. M., \& Mehta, P. K. (2004). Pozzolanic and Cementitious Materials. London: Taylor \& Francis.

[16]. Mehta, P. K. \& Pirtz, D. (2000). Use of rice husk ash to reduce temperature in high strength mass concrete. ACI Journal Proceedings, 75:60-63.

[17]. Rukzon, S., \& Chindaprasirt, P. (2006). Strength of ternary blended cement mortar containing Portland cement, rice husk ash and fly ash. J. Eng. Inst. Thailand, 17: 33-38 (547-551).

[18]. Rukzon, S., Chindaprasirt, P., \& Mahachai, R. (2009). Effect of grinding on chemical and physical properties of saw dust ash. International Journal of Minerals, Metallurgy and Materials, 16 (2): 242-247.

[19]. Sakr, K. (2006). Effects of Silica Fume and Rice Husk Ash on the Properties of Heavy Weight Concrete. Journal of Materials in Civil Engineering, 18(3): 367-376.

[20]. Saraswathy, V., \& Song, H. (2007). Corrosion performance of rice husk ash blended concrete. Construction and Building Materials, 21 (8): p.1779-1784.

[21]. Wada, I., Kawano, T., \& Mokotomaeda, N. (2000). Strength properties of concrete incorporating highly reactive rice-husk ash. Transaction of Japan Concrete Institute, 21 (1): p. 57-62. 